\title{
PENERAPAN METODE SOSIODRAMA UNTUK PEMBENTUKAN SIKAP DISIPLIN SISWA
}

\author{
Syaiful', Maemunah², Deviana Mayasari ${ }^{3}$
}

\author{
${ }^{1}$ Pendidikan Pancasila dan Kewarganegaraan, Universitas Muhammadiyah Mataram, syaiful23@gmail.com \\ ${ }^{2}$ Program Studi Pendidikan Pancasila dan Kewarganegaraan FKIP Universitas Muhammadiyah Mataram, maemunahabdullah@gmail.com \\ ${ }^{3}$ Program Studi Pendidikan Pancasila dan Kewarganegaraan FKIP Universitas Muhammadiyah Mataram, deviana_mayasari@yahoo.com
}

INFO ARTIKEL
Riwayat Artikel:
Diterima: $\quad$ 10-Januari-
2017
Disetujui: 15 Maret-2017

Kata Kunci:

Metode

Sosiodrama

Disiplin

\section{A. LATAR BELAKANG}

Menurunya nilai moral siswa dipengaruhi kurangnya sikap disiplin siswa dalam mengaplikasikan sikap disiplin dalam kehidupan sehari-hari. Disiplin merupakan cara masyarakat mengajarkan pada anak mengenai perilaku moral yang diterima oleh kelompok. Tujuannya adalah untuk memberitahukan kepada anak perilaku mana yang baik dan mana yang buruk serta mendorong untuk berperilaku agar sesuai dengan standar yang diperlukan. Hal yang diperlukan adalah

\begin{abstract}
Abstrak: Disiplin merupakan salah satu tolak ukur untuk membentuk sikap disiplin siswa, oleh karena itu guru dan strategi pembelajaran sangat mempengaruhi karakter siswa. Pendidikan Pancasila dan Kewarganegaraan merupakan pembelajaran yang memberikan bekal siswa dengan budi pekerti, pengetahuan dan kemampuan dasar berkenaan dengan hubungan antara warga negara dengan Negara.Tujuan penelitian ini untuk mendeskripsikan penerapan metode sosiodrama untuk pembentukan sikap disiplin siswa. Rancangan penelitian yang digunakan yaitu penelitian tindakan kelas dengan pendekatan yang digunakan dalam penelitian ini adalah pendekatan kualitatif dan pendekatan kuantitatif. Metode pengumpulan data menggunakan observasi, angket dan dokumentasi. Teknik analisis data digunakan analisis data aktivitas siswa, keterlaksanaan pembelajaran guru, pembentukan sikap disiplin siswa dan analisis evaluasi. Hasil penelitian menunjukkan bahwa penerapan metode sosiodrama dapat meningkatkan pembentukan sikap di siplin dan hasil belajar siswa. Hal ini dikarenakan adanya peningkatan pembentukan sikap disiplin dan hasil belajar, serta kegiatan mengajar yang dilakukan oleh guru, karna penerapan metode sosiodrama memiliki kelebihan dapat memberikan kesempatan kepada para siswa untuk lebih akatif dalam proses belajar mengajar dan dapat memberikan kesempatan pada para siswa untuk mengasah keterampilan berdidkusi.
\end{abstract}

\begin{abstract}
Discipline is one of the benchmarks for forming student discipline, therefore teachers and learning strategies greatly influence the character of students. Pancasila and Citizenship Education is learning that provides students with the skills, knowledge and basic abilities related to the relationship between citizens and the State. The purpose of this study is to describe the application of sociodrama methods to the formation of student discipline attitudes. The research design used is classroom action research with the approach used in this study is a qualitative approach and a quantitative approach. Methods of collecting data using observation, questionnaires, tests and documentation. Data analysis techniques are used to analyze student activity data, implementation of teacher learning, formation of student discipline attitudes and evaluation analysis. The results showed that the application of the sociodrama method can improve the formation of attitudes in the discipline and student learning outcomes. This is due to an increase in the formation of disciplinary attitudes and learning outcomes, as well as teaching activities carried out by teachers, because the application of sociodrama methods has the advantage of being able to provide opportunities for students to be more active in the learning process and can provide opportunities for students to hone education skills.
\end{abstract}

peran para orang tua, orang dewasa ataupun guru untuk bisa memberikan stimulasi dan intervensi apa kepada anak agar anak mengetahui perilaku-perilaku yang diinginkan oleh standar kelompok sosialnya[1].

Fenomena-fenomena yang mengarah pada gagalnya pendidikan, seperti kondisi moral/akhlak generasi muda yang rusak/hancur (pergaulan bebas, narkoba), pengangguran yang semakin meluas, rusaknya moral bangsa yang akut (korupsi, kriminal, asusila) dan lain sebagainya. Peserta didik sebagai obyek pendidikan merupakan korban dari proses pendidikan yang ada jika 
sistem pendidikan nasional mengalami reduksi makna pendidikan yang hanya menjadi sekedar penyampaian pengetahuan (transfer of knowleges) belaka, maka pada saat itu lah peserta didik telah diberi pelajaran yang sangat mempengaruhi pola pikir hidupnya kelak dalam pengambilan keputusan. Maka diperlukan pendidikan moral sebagai faktor penting untuk tercapainya keberhasilan demokrasi suatu Negara[2].

Belajar merupakan aktivitas manusia yang penting dan tidak dapat dipisahkan dari kehidupan manusia, sejak lahir sampai akhir hayat manusia tidak pernah lepas dari proses belajar. Dimulai dari lingkungan keluarga, masyarakat dan sekolah manusia selalu dituntut untuk terus belajar. Sekolah adalah suatu wadah yang paling erat hubungannya dengan kegiatan pembelajaran. Kualitas pembelajaran pada suatu sekolah dapat dilihat dari segi proses dan segi hasil pembelajaran pada sekolah tersebut[3]. Apabila proses dan hasilnya baik, maka dapat dikatakan bahwa kualitas pembelajaran juga baik. Keberhasilan suatu pembelajaran dapat dipengaruhi oleh metode pembelajaran yang digunakan guru. Jika metode pembelajarannya menarik dan terpusat pada siswa (student-centered learning) maka motivasi dan perhatian siswa akan meningkat dan selanjutnya kualitas pembelajaran juga dapat meningkat.

Pendidikan merupakan kebutuhan spiritual yang sangat penting dalam usaha pengembangan kualitas sumber daya manusia. Untuk itu dituntut usaha melaksanakan pendidikan yang terus-menerus dan bersifat fleksibel, yaitu pendidikan yang harus disesuaikan dengan perkembangan ilmu pengetahuan dan teknologi. Dengan demikin peningkatan mutu serta penyempurnaan sitem pendidikan sangat diperlukan untuk mencapai tujuan pembangunan bangsa. Untuk itu diperlukan sumber daya manusia yang berkualitas. Dalam hal ini, khususnya guru sebagai tenaga pendidik mempunyai peran dan tanggung jawab untuk menyiapkan peserta didik yang dapat bersaing dalam era globalisasi sekarang dan masa yang akan dating.

Salah satu pembelajaran yang diajarkan di sekolah adalah mata pelajaran Pendidikan Pancasila dan Kewarganegaraan. Pendidikan Pancasila dan Kewarganegaraan adalah wahana untuk mengembangkan dan melestarikan nilai luhur dan moral yang berakar pada budaya bangsa Indonesia yang diharapkan dapat diwujudkan dalam bentuk dan perilaku dalam kehidupan sehari-harl siswa, baik sebagal individu maupun sebagai masyarakat warga negara dan makhluk ciptaan Tuhan Yamg Maha Esa[4]. Ahli lain mengemukakan bahwa Pendidikan Pancasila dan Kewarganegaraan merupakan pembelajaran yang memberikan bekal siswa dengan budi pekerti, pengetahuan dan kemampuan dasar berkcnaan dengan hubungan antara warga negara dengan negara serla pendidikan terdahulu bela negara agar menjadi warga negara yang dapat diandalkan oleh bangsa dan Negara[5].

Dalam proses belajar mengajar di kelas terdapat keterkaitan yang erat antara guru, siswa, kurikulum, sarana dan prasarana. Guru mempunyai tugas untuk memilih metode pembelajaran yang tepat sesuai dengan materi yang disampaikan demi tercapainya tujuan pendidikan. Sampai saat ini masih banyak ditemukan kesulitan-kesulitan yang dialami siswa di dalam mempelajari PPKn. PPKn merupakan mata pelajaran yang bersifat pasti, sehingga dituntut kemampuan guru untuk dapat mengupayakan model yang tepat sesuai dengan tingkat perkembangan mental siswa. Untuk itu diperlukan metode pembelajaran yang dapat membantu siswa untuk mencapai kompetensi dasar dan indikator pembelajaran.

Pada kenyataannya saat ini masih banyak guru yang masih menggunakan metode pembelajaran konvensional yang berpusat pada guru (teacher oriented), hal ini terlihat jelas dari hasil observasi di SMP Negeri 21 Mataram, dimana dalam proses belajar mengajar guru lebih sering menggunakan metode mengajar yang monoton, yaitu dengan metode ceramah, dan tanya jawab. Hal ini tentu akan menimbulkan kejenuhan bagi siswa dalam kegiatan belajar mengajar. Oleh karena itu sudah selayaknya dalam kegiatan belajar mengajar, guru memvariasikan cara mengajarnya dengan Metode sosiodrama.

Dari hasil pengamatan peneliti didalam proses kegiatan belajar mengajar di SMP Negeri 21 Mataram didapat informasi awal bahwa dari semua kelas yang ada di SMP Negeri 21 Mataram baik kelas VII sampai dengan Kelas IX dinyatakan permasalahan pembelajaran lebih banyak terjadi dikelas VII. Berdasarkan hasil observasi awal melalui observasi di kelas VII SMP Negeri 21 Mataram ditemukan kemungkinan penyebab timbulnya masalah tersebut yaitu: (1) Masih banyak siswa yang tidak memperhatikan guru dalam menjelaskan materi pembelajaran. (2) Sering kali ketika siswa diberi kesempatan untuk bertanya oleh gurunya siswa hanya berdiam, sementara siswa belum tentu memahami materi yang disampaikan guru. (3) Kadang kala jika ada siswa yang bertanya kepada guru, teman-temannya malah melecehkannya. (4) siswa masih takut menjawab pertanyaan yang diajukan oleh guru SMP Negeri 21 Mataram, sehingga menyebabkan daya berpikir kritis siswa terhadap materi yang diajarkan oleh guru masih rendah, (5) pembelajaran yang dilakukan oleh guru masih dominan menggunakan metode ceramah, tidak memanfaatkan berbagai strategi dan model-metode pembelajaran yang lain.

Melihat permasalahan-permasalahan diatas maka Metode sosiodrama, dipandang relevan untuk meningkatkan pembentukan sikap disiplin siswa. Proses pembentukan sikap disiplin adalah proses yang terjadi karena pengalaman-pengalaman pribadi seseorang dengan objek tertentu, seperti orang, benda atau 
peristiwa, dengan cara menghubungkan objek tersebut dengan pengalaman-pengalaman lain dimana seseorang telah memiliki sikap tertentu terhadap pengalaman itu atau melalui proses belajar sosial dengan orang lain yang betujuan meningkatkan disiplin anak[6]. Metode sosiodrama adalah cara mengajar yang memberikan kesempatan anak didik untuk melakukan kegiatan memainkan peran tertentu yang terdapat dalam kehidupan masyarakat[7].

Penerapan metode sosiodrama sesuai untuk mata pelajaran PPKn karena dapat mendorong siswa untuk berusaha membutuhkan pertukaran pikiran dan informasi antar siswa yang dihadapi, sehingga aktivitas dan hasil belajar dapat ditingkatkan dan memberikan peluang yang lebih besar untuk meningkatkan belajar PPKn siswa. Sebab Metode sosiodrama siswa akan dapat memiliki keterampilan dalam menyelesaikan permasalahan. Siswa akan memiliki pengalaman belajar yang berbeda dan bervariasi mengenai suatu konsep atau topik dalam suasana yang menyenangkan sehingga lebih merangsang minat peserta didik untuk belajar sehingga siswa akan lebih termotivasi dalam belajarnya.

Penerapan Metode sosiodrama memiliki kelebihan dapat mengasah kemapuan siswa dalam memecahkan masalah, mengajarkan siswa untuk berprilaku disiplin baik dilingkungan formal maupun non formal, mengeksperisikan sesuatu secara efektif serta menekankan siswa pada makna ide-ide yang dapat diperkuat melalui aktifitas yang kreatif dengan cara melihat sesuatu yang lebih luas. Selai itu, penerapan Metode sosiodrama mengefektifkan partisipasa siswa dalam pembelajaran serta mengurangi adanya dominasi partisipasi oleh satu atau beberapa orang saja dalam diskusi. Tujuan penelitian adalah untuk mendeskripsikan strategi guru dalam penerapan metode sosiodrama untuk pembentukan sikap disiplin siswa kelas VII SMP Negeri 21 Mataram.

\section{B. METODE PENELITIAN}

1. Metode yang Digunakan

Metode penelitian yang digunakan peneliti dalam penelitian ini adalah Penelitian Tindakan Kelas (Clasroom Action Research). Secara singkat Penelitian Tindakan Kelas (PTK) adalah suatu pencermatan terhadap kegiatan belajar berupa sebuah tindakan, yang sengaja dimunculkan dan terjadi dalam sebuah kelas secara bersama[8]. Penelitian tindakan kelas adalah penelitian yang dilakukan guru atau peneliti didalam kelas, dengan tujuan untuk memperbaiki kinerja guru sehingga hasil belajar siswa dapat meningkat[9]. Penelitian Tindakan Kelas merupaka pencermatan terhadap kegiatan belajar berupa sebuah tindakan, yang sengaja dimunculkan dan terjadi dalam sebuah kelas secara bersamaan[10].

2. Subjek Penelitian

Pada penelitian ini yang menjadi subjek penelitian adalah siswa kelas VII di SMP Negeri 21 Mataram.
Pemilihan kelas VII A sebagai subjek penelitian karena kelas VIIA memiliki nilai ketuntasan klasikal yang paling rendah dengan ketuntasan klasikal sebesar 72,97\%. Aktivitas belajar siswa dan guru dikatakan meningkat apabila setiap siklusnya minimal berkategori aktif. Penelitian dikatakan berhasil jika nilai rata-rata daya serap siswa meningkat setelah menerapkan strategi sosiodrama dengan ketuntasan klasikal $\geqslant 85 \%$ dan mendapat nilai kriteria ketuntasan minimal $(\mathrm{KKM}) \geqslant 75$ pada saat evaluasi tiap siklus[11].

\section{Prosedur Penelitian}

Prosedur penelitian ini mneggunakan dua siklus. Setiap siklus dalam Penelitian Tindakan Kelas terdiri dari 4 (empat) tahap yaitu perencanaan, pelaksanaan tindakan, observasi dan refleksi. Secara rinci perencanaan tindakan untuk setiap siklus dapat dijabarkan sebagai berikut:

a. Siklus pertama

1) Perencanaan tindakan

Perencanaan adalah berupa identifikasi masalah dan penetapan alternatif pemecahan masalah[8]. Tahapan ini berupa penyusuan rancangan tindakan yang menjelaskan tentang apa,mengapa,kapan,dimana,oleh siapa,dan bagaimana tindakan tersebut akan dilakukan. Dalam tahap ini. Hal-hal yang dilakukan oleh peneliti adalah :

a) Membuat Rencana Pelaksanaan Pembelajaran (RPP).

b) Menyusun lembar observasi untuk mencatat aktivitas belajar siswa

c) membuat angket pembentukan sikap siswa

d) Merancang alat evaluasi yakni berupa tes hasil belajar dalam bentuk pilihan ganda untuk mengetahui hasil belajar yang diperoleh siswa.

2) Pelaksanakan tindakan

Merupakan tindakan yang akan dilakukan dalam proses pembelajaran dengan mengacu pada skenario pembelajaran[8]. Pada tahap ini peneliti akan melaksanakan kegiatan pembelajaran sesuai dengan skenario dan rencana pelaksaan pembelajaran (RPP) yang telah disusun terlebih dahulu. Kegiatan yang dilaksanakan pada tahap ini adalah melaksanakan semua hal yang telah direncanakan pada tahap perencanaan sesuai dengan rencana pelaksanaan pembelajaran.

3) Observasi dan evaluasi

Melakukan observasi dengan melakukan penilaian erdasarkan format observasi selama berlansungnya pelaksanaan tindakan melalui interaksi akademik (antar siswa maupun siswa-guru). Sedangkan evaluasi dilaksanakan pada akhir tindakan dengan memberi tes, observasi, angket, dan lain-lain[8]. Kegiatan observasi dilakukan secara kontinu setiap kali pembelajaran berlansung dalam pelaksaan tindakan dengan mengamati kegiatan siswa /aktivitas siswa dalam hal ini yang bertidak sebagai observer adalah peneliti dan guru mata pelajaran PKn yang mengajar pada kelas tempat penelitian. Setelah melaukan pelaksanaan tindakan yag sesuai dengan tahap-tahapan seperti yang jelaskan 
diatas, maka peneliti melakukan Evaluasi dengan tujuan untuk mengetahui keberhasilan siswa dalam proses belajar mengajar, dan kegiatan evaluasi dilakukan setelah akhir setiap siklus dengan memberi tes pilihan ganda yang dikerjakan secara individu.

Kegiatan observasi dilakukan secara kontinu pada setiap pembelajaran. Selama berlangsungnya pelaksanaan tindakan, kegiatan pembelajaran oleh guru sesuai dengan rencana pelaksanaan pembelajaran dan aktivitas belajar siswa dicatat dalam lembar observasi yang telah disediakan. Sedangkan evaluasi dilakukan dengan memberikan tes pilihan ganda pada akhir setiap siklus untuk mengetahui sejauh mana penguasaan siswa terhadap konsep yang telah diberikan.

\section{4) Refleksi}

Mengkaji secara menyeluruh tindakan yang telah dilaukan berdasarkan data yang telah terkumpul, kemudian dilaukan evaluasi guna menyempurnakan tindakan[8]. Refleksi dilakukan setiap akhir siklus,pada tahap ini peneliti sebagai pengajar bersama guru yang bertindak sebagai Observer. Mengkaji hasil yang diperoleh dari pemberian tindakan pada setiap siklus. Kegiatan pada tahap refleksi ini juga mengkaji kekurangan dan hambatan yang muncul pada saat berlansungnya proses belajar mengajar untuk diperbaiki pada siklus selanjutnya. Hasil refleksi pada siklus I untuk merencanakan pada siklus II untuk merencanakan pada siklus berikutnya. Refleksi dilakukan pada akhir setiap siklus. Pada tahap ini, peneliti mengkaji hasil yang diperoleh dari pemberian tindakan pada siklus I, sebagai acuan dalam refleksi ini adalah hasil observasi dan evaluasi. Hasil refleksi ini digunakan sebagai dasar untuk memperbaiki serta menyempurnakan perencanan dan pelaksanaan tindakan pada siklus II.

b. Siklus Kedua

Kegiatan yang dilaksanakan pada siklus kedua sama dengan kegiatan yang dilaksanakan pada siklus satu. Apa yang menjadi kekurangan pada siklus pertama disempurnakan pada siklus kedua.

4. Metode Pengumpulan Data

\section{a. Metode Observasi}

Metode observasi diartikan sebagai pengamatan dan pencatatan secara sistimatis terhadap gejala yang tampak pada objek penelitian[12]. Observasi adalah penghimpunan bahan-bahan keterangan yang dilakukan dengan melakukan pengamatan dan pencatatan secara sistimatis terhadap berbagai fenomena yang dijadikan objek pengamatan[11]. Observasi adalah dasar semua ilmu pengetahuan. para ilmuwan hanya dapat bekerja berdasarkan data, yaitu fakta mengenai dunia kenyataan yang diperoleh melalui observasi[11].

Observasi bisa diartikan sebagai pengamatan dan pencatatan secara sistimatis terhadap gejala yang tampak terhadap objek penelitian observasi merupakan pengumpulan data dengan melakukan pengamatan secara langsung pada objek penelitian sekaligus mencatat gejala-gejala serta fenomena yang tampak pada objek penelitian guna mendapatkan informasi yang relevan mengenai permasalahan yang sedang diteliti.

Dari uraian di atas, maka dapat ditarik kesimpulan bahwa observasi merupakan alat pengumpulan data yang dilakukan secara sistimatis, observasi dilakukan menurut prosedur dan aturan tertentu sehingga dapat diulangi kembali oleh peneliti. Alat pengumpulan menggunakan observasi berupa lembar observasi aktifitas belajar siswa dan lembar observasi keterlaksanaan pembelajaran oleh guru.

Adapun yang dilakukan dalam penelitian ini, untuk mengamati Aktivitas siswa selama proses pembelajaran yaitu dikumpulkan dengan observasi atau pengamatan secara langsung yang sesuai dengan ketentuan yang ditetapkan oleh KTSP (Kurikulum Tingkat Satuan Pendidikan). Adapun instrumen yang digunakan dalam pengumpulan data ini adalah pedoman observasi yang berisi deskriptor-deskriptor dalam indikator prilaku siswa dan guru sesuai dengan strategi sosiodrama. Setiap deskriptor pada masing-masing indikator yang nampak akan dicatat pada lembar observasi.

\section{b. Metode Dokumentasi}

Dokumentasi berasal dari asal kata "Dokumen" yang artinya barang-barang tertulis. Didalam melaksanakan metode dokumentasi, peneliti menyelidiki benda-benda tertulis seperti buku notulen rapat, catatan harian, arsip dan sebagainya[8]. Metode dokumentasi adalah suatu metode pengambilan data dari sumber-sumber yang tertulis baik berupa surat foto, gambar, tabel, grafik maupun keterangan tertulis lainya.

Dari penguraian diatas dapat diketahui bahwa metode dokumentasi adalah suatu metode penelitian yang ditunjukan kepada penguraian dan penjelasan terhadap apa yang telah berlangsung melalui sumbersumber dokumen dalam mengali suatu data. Metode dokumentasi di gunakan dalam penelitian ini berupa data jumlah siswa, jumlah guru, keadaan ruang, dan fasilitas belajar, serta data-data lain yang diperlukan dalam penelitian di SMP Negeri 21 Mataram Tahun Pelajaran 2016-2017.

c. Metode Angket

Angket adalah satuan data pernyataan atau pertanyaan tertulis yang harus dijawab oleh guru yang menjadi sasaran dari peneliti tersebut ataupun orang lain[9]. Angket adalah sejumlah pernyataan tertulis yang digunakan untuk memperoleh informasi dari responden dalam arti laporan tentang kepribadian atau hal-hal yang dia ketahui[8]. Angket yang digunakan berupa uraian nontes berupa pernyataan tentang sikap disiplinj siswa yang dibagikan secara terbuka.

\section{HASIL DAN PEMBAHASAN}

\section{Hasil Penelitian}

a. Hasil Siklus I

1) Tahapan perencanaan

Tahap perencanaan pada siklus I pertemuan 1 dihasilkan beberapa perangkat pembelajaran dan instrumen penelitian. Perangkat pembelajaran yang 
dihasilkan adalah Rencana Pelaksanaan Pembelajaran (RPP) dan Buku Guru. Langkah-langkah pembelajaran yang disusun dalam RPP didesain sesuai dengan langkah-langkah penerapan metode sosiodrama.

2) Tahapan pelaksanaan

Setelah selesai menyusun segala sesuatu yang dibutuhkan dalam penelitian, maka seluruh kegiatan yang tersusun dalam rencana penelitian semaksimal mungkin harus dilaksanakan sesuai dengan skenario/RPP yang telah dibuat. Perencanaan tidak banyak bermakna jika tidak mampu dilaksanakan dalam tindakan nyata, bahkan salah satu indikator keberhasilan penelitian adalah apabila seluruh rencana terukur pelaksanaannya. Siswa dinilai berdasarkan format penilaian yang telah ditentukan sebelumnya.

Dalam tahap pelaksanaan ini, peneliti hanya mempersiapkan RPP dan Silabus yang sesuai dengan pembelajaran yang akan dilaksanakan. Pembelajaran akan berjalan efektif dan sesuai dengan harapan apabila pemilihan metode pembelajaran disesuaikan dengan situasi dan kondisi peserta didik. Oleh karena itu, pada pembelajaran menulis karangan deskripsi yang menggunakan penerapan metode sosiodrama sangat sesuai. Karena dengan penerapan metode sosiodrama siswa akan lebih mudah menanggapi pembelajaran menulis yang dilakukan oleh siswa tersebut.

a) Tahap Awal

Pada tahap awal pembelajaran guru meminta siswa untuk berdoa agar pembelajaran bisa berjalan dengan lancar. Kemudian, guru mengecek kehadiran siswa satu persatu dengan cara mengabsen siswa. Selanjutnya, guru menyampaikan tujuan dan memberikan apresiasi tentang hal-hal yang harus diperhatikan dalam pembelajaran menulis sehingga siswa dapat mengetahui materi yang akan dibahas. Saat guru mengajukan pertanyaan tentang materi norma dengan antusias menjawab pertanyaan tersebut.

b) Tahap Inti

Tahap selanjutnya guru menjelaskan tentang materi norma dengan menggunakan penerapan metode sosiodrama. Setelah itu, guru meminta siswa dari untuk aktif dalam belajar. Guru kemudian memberikan contoh soal yang akan dikerjakan oleh siswa. Setiap siswa mempersentasekan di depan kelas yang disampaikan oleh perwakilan dari masing-masing kelompok, dengan menggunakan format penilaian yang telah dibagikan guru sebelumya. Guru memantau kinerja tiap-tiap siswa dan membimbing siswa yang mengalami kesulitan dalam memberikan tanggapan terhadap materi yang disampaikan dari masing-masing siswa. Kemudian guru memberikan penilaian terhadap masing-masing individu sesuai dengan aspek penilaian yang telah dibuat.

c) Tahap penutup

Setelah penilaian selesai, guru memberikan umpan balik kepada siswa dengan menayakan bagaimana pendapat siswa tentang pembelajaran hari ini, kemudian guru bersama siswa menyimpulkan hasil pembelajaran.

3) Observasi dan evaluasi

Tahap ini merupakan pelaksanaan dari RPP yang sudah didesain mengikuti penerapan penerapan metode sosiodrama. Selama pembelajaran berlangsung dilakukan pengamatan terhadap aktivitas guru dan pembentukan sikap disiplin siswa. Selengkapnya akan dijabarakan pada tabel sebagai berikut:

1) Data Aktivitas Guru Tabel 1
Ringkasan Aktivitas Guru Siklus I

\begin{tabular}{|l|l|l|l|}
\hline \multirow{2}{*}{ No } & \multicolumn{1}{|c|}{ Idikator } & \multicolumn{2}{|c|}{ Siklus I } \\
\cline { 3 - 4 } & & $\begin{array}{c}\text { Pertemuan } \\
1\end{array}$ & \multicolumn{1}{|c|}{$\begin{array}{c}\text { Pertemuan } \\
2\end{array}$} \\
\hline 1 & $\begin{array}{l}\text { Skor yang } \\
\text { harus } \\
\text { diperoleh }\end{array}$ & 23 & 15 \\
\hline 2 & $\begin{array}{l}\text { Skor yang } \\
\text { diperoleh }\end{array}$ & 13 & 21 \\
\hline 3 & $\begin{array}{l}\text { Prosentase } \\
\text { keterlaksana } \\
\text { an }\end{array}$ & $36,11 \%$ & $58,33 \%$ \\
\hline 4 & Kategori & $\begin{array}{l}\text { Kurang } \\
\text { Baik }\end{array}$ & $\begin{array}{l}\text { Cukup } \\
\text { Baik }\end{array}$ \\
\hline
\end{tabular}

Berdasarkan hasil analisis lembar observasi aktifitas guru di atas dengan jumlah skor pada siklus I pertemuan 1 adalah 12 dengan kategori kurang baik mengalami peningkatan pada siklus I pertemuan 2 dengan jumlah skor sebesar 19 kategori cukup baik. Memperhatikan data pada tabel 1 tersebut maka kekurangan-kekurangan yang muncul pada siklus I adalah sebagai berikut:

a. Guru tidak menyiapkan materi secara matang

b. Guru kurang optimal dalam menyampaikan tujuan pembelajaran

c. Guru tidak menyiapkan segala perencanaan proses belajar mengajar

d. Guru masih terfokus pada kelompok-kelompok tertentu

e. Interaksi belajar mengajar selalu monoton dan satu arah.

Kegiatan guru belum dilaksanakan dengan baik dan mengalami peningkatan dari siklus I pertemuan 1 dengan persentase sebesar $33,3 \%$ menjadi $52,8 \%$ pada pertemuan 2.

2) Data Pembentukan sikap disiplin siswa

Untuk mengetahui Pembentukan sikap disiplin siswa, dilakukan observasi oleh observer. Dari hasil observasi Pembentukan sikap disiplin siswa diperoleh data sebagai berikut :

Tabel 2.

Ringkasan Pembentukan Sikap Disiplin Siswa Siklus I

\begin{tabular}{|c|c|c|c|}
\hline \multirow[b]{2}{*}{$\begin{array}{l}\mathrm{N} \\
\mathrm{o}\end{array}$} & \multirow[b]{2}{*}{ Idikator } & \multicolumn{2}{|c|}{ Siklus I } \\
\hline & & $\begin{array}{c}\text { Pertemuan } \\
1\end{array}$ & $\begin{array}{c}\text { Pertemuan } \\
2\end{array}$ \\
\hline 1 & $\begin{array}{l}\text { Skor yang } \\
\text { harus } \\
\text { diperoleh }\end{array}$ & 20 & 20 \\
\hline 2 & $\begin{array}{l}\text { Skor yang } \\
\text { diperoleh }\end{array}$ & 7 & 11 \\
\hline 3 & Prosentase & $35 \%$ & $55 \%$ \\
\hline 4 & Kategori & $\begin{array}{l}\text { Kurang } \\
\text { Tinggi }\end{array}$ & $\begin{array}{l}\text { Cukup } \\
\text { Tinggi }\end{array}$ \\
\hline
\end{tabular}

Berdasarkan tabel hasil observasi diatas skor Pembentukan sikap disiplin siswa pada pertemuan 1 adalah 7 dengan kriteria kurang tinggi. Sedangkan pada pertemuan 2 diperoleh skor Pembentukan sikap disiplin siswa 11 dengan kategori cukup tinggi. Berdasarkan hasil observasi Pembentukan sikap disiplin siswa selama proses pembelajaran berlangsung dapat dilihat bahwa kegiatan siswa yang sudah berjalan dengan baik adalah kesiapan dan antusiasme siswa dalam mengikuti kegiatan pembelajaran. Selain itu terdapat pula 
kekurangan pada pelaksanaan pembelajaran. Kekurangan-kekurangan itu antara lain:

(1) Sebagian besar siswa tidak serius pada waktu kerja kelompok sehingga kerjasama antara anggota kelompok kurang optimal.

(2) Sebagian besar siswa masih takut atau malu untuk bertanya kepada guru.

(3) Ada siswa yang tidak betah/tidak cocok dengan anggota kelompoknya sehingga kerjasama kelompok kurang optimal

(4) Beberapa siswa masih kurang menguasai materi, karena masih banyak siswa yang kesulitan mengerjakan soal evaluasi.

Aktivitas belajar siswa mengalami peningkatan dari siklus I pertemuan 1 sebesar $35 \%$ menjadi $55 \%$ pada pertemuan 2.

3) Evaluasi

Data hasil evaluasi belajar siswa pada siklus pertama adalah sebagai berikut :

Tabel 3

Data Prestasi Belajar Siswa Siklus I

\begin{tabular}{|l|l|}
\hline Tes & Siklus I \\
\hline Jumlah Siswa & 31 \\
\hline Nilai Total & 2180 \\
\hline Nilai Rata-rata & 70,32 \\
\hline Siswa Yang Tidak Tuntas & 8 \\
\hline Siswa Yang Tuntas & 23 \\
\hline Nilai Tertingi & 80 \\
\hline Nilai Terendah Ketuntasan & 45 \\
\hline $\begin{array}{l}\text { Persentase } \\
\text { Klasikal }\end{array}$ & T4,20\% \\
\hline Kategori & \\
\hline
\end{tabular}

Tes pilihan ganda sebanyak 20 soal (Lampiran 4) dengan alokasi waktu 45 menit. Dari hasil analisis siklus I diperoleh nilai rata-rata siswa 70,32 dengan nilai tertinggi 80 dan nilai terendah 45. Nilai rata-rata siswa pada siklus I masih jauh dari indikator kerja yang diharapkan. Oleh sebab itu penelitian dilanjutkan ke siklus II. Untuk mengetahui terjadi tidaknya peningkatan rata-rata nilai prestasi siswa maka dilanjutkan dengan siklus II. Hasil evaluasi ini juga menunjukan bahwa terdapat 8 orang siswa masih belum tuntas belajarnya, sehingga perla dilakukan bimbingan yang lebih serius.

4) Refleksi.

Pada pertemuan siklus I terdapat kekurangan yang tentunya akan diperbaiki pada siklus II. Adapun perbaikan-perbaikan yang akan dilaksanakan pada siklus II yaitu guru selalu :

(1) Meminta kepada siswa untuk lebih serius mengerjakan tugas pada waktu kerja kelompok. Perbaikan ini termasuk ke dalam tahap identifikasi masalah.

(2) Meminta siswa untuk tidak malu dan takut bertanya karena itu akan merugikan diri siswa sendiri.

(3) Memindahkan siswa yang tidak betah dengan anggota kelompoknya dan membentuk kelompok baru sehingga siswa dapat bekerjasama dengan anggota kelompoknya
(4) Menekankan kepada siswa agar mencoba mengerjakan soal latihan yang diberikan bukan hanya menyalin jawaban temannya saja. Perbaikan ini termasuk ke dalam tahap aplikasi.

(5) Meminta siswa untuk menyimpulkan hasil pembelajaran perbaikan termasuk dalam tahap refleksi.

(6) Mengulas kembali materi sebelumnya yang belum dikuasai dan memberikan kesempatan kepada siswa untuk menanyakan hal-hal yang belum jelas.

(7) Membesarkan suara dan meminta siswa untuk tenang

(8) Meminta siswa supaya saling membantu antara kelompok dan meminta siswa yang sudah mengerti agar menjelaskan temannya yang belum mengerti. Perbaikan ini termasuk ke dalam tahap identifikasi masalah.

b. Hasil Siklus II

1) Tahapan Perencanaan

Seperti halnya pada siklus I, tahap perencanaan pada siklus II pertemuan 1 ini dihasilkan perangkat pembelajaran berupa RPP, Buku Siswa, dan LKS. Sedangkan instrumen yang digunakan sama dengan pada siklus I, yaitu lembar pengamatan Pembentukan sikap disiplin siswa, dan guru serta lembar tes hasil belajar. Kedua instrumen tersebut sama dengan yang digunakan pada siklus I.

2) Pelaksanaan

Setelah selesai menyusun segala sesuatu yang dibutuhkan dalam penelitian, maka seluruh kegiatan yang tersusun dalam rencana penelitian semaksimal mungkin harus dilaksanakan sesuai dengan skenario/RPP yang telah dibuat. Perencanaan tidak banyak bermakna jika tidak mampu dilaksanakan dalam tindakan nyata, bahkan salah satu indikator keberhasilan penelitian adalah apabila seluruh rencana terukur pelaksanaannya. Siswa dinilai berdasarkan format penilaian yang telah ditentukan sebelumnya.

Dalam tahap pelaksanaan ini, peneliti hanya mempersiapkan RPP dan Silabus yang sesuai dengan pembelajaran yang akan dilaksanakan. Pembelajaran akan berjalan efektif dan sesuai dengan harapan apabila pemilihan metode pembelajaran disesuaikan dengan situasi dan kondisi peserta didik. Oleh karena itu, pada pembelajaran menulis karangan deskripsi yang menggunakan penerapan metode sosiodrama sangat sesuai. Karena dengan penerapan metode sosiodrama siswa akan lebih mudah menanggapi pembelajaran menulis yang dilakukan oleh siswa tersebut.

\section{Tahap awal}

Pada tahap awal pembelajaran guru meminta siswa untuk berdoa agar pembelajaran bisa berjalan dengan lancar. Kemudian, guru mengecek kehadiran siswa satu persatu dengan cara mengabsen siswa. Selanjutnya, guru menyampaikan tujuan dan memberikan apresiasi tentang hal-hal yang harus diperhatikan dalam pembelajaran menulis sehingga siswa dapat mengetahui materi yang akan dibahas. Saat guru mengajukan pertanyaan tentang materi norma dengan antusias menjawab pertanyaan tersebut.

\section{Tahap inti}

Guru menjelaskan tentang materi norma dengan menggunakan penerapan metode sosiodrama. Setelah 
itu, guru meminta siswa dari siswa untuk menulis di depan kelas. Guru memantau kinerja tiap-tiap siswa dan membimbing siswa yang mengalami kesulitan dalam memberikan tanggapan terhadap menulis yang disampaikan dari masing-masing siswa. Kemudian guru memberikan penilaian terhadap masing-masing individu sesuai dengan aspek penilaian yang telah dibuat oleh guru.

3. Tahap penutup

Setelah penilaian selesai, guru memberikan umpan balik kepada siswa dengan menayakan bagaimana pendapat siswa tentang pembelajaran hari ini, kemudian guru bersama siswa menyimpulkan hasil pembelajaran.

3) Observasi dan evaluasi

Tahap ini merupakan pelaksanaan dari RPP yang sudah didesain mengikuti penerapan penerapan metode sosiodrama. Selama pembelajaran berlangsung dilakukan pengamatan terhadap aktivitas guru dan pembentukan sikap disiplin siswa. Selengkapnya akan dijabarakan pada tabel sebagai berikut:

1. Data Aktivitas Guru

Tabel 4.

Ringkasan Aktivitas Guru Siklus II

\begin{tabular}{|l|l|l|l|}
\hline \multirow{2}{*}{ No } & \multicolumn{1}{|c|}{ Idikator } & \multicolumn{2}{|c|}{ Siklus II } \\
\cline { 3 - 4 } & $\begin{array}{c}\text { Pertemuan } \\
1\end{array}$ & \multicolumn{1}{|c|}{$\begin{array}{c}\text { Pertemuan } \\
2\end{array}$} \\
\hline 1 & $\begin{array}{l}\text { Skor yang harus } \\
\text { diperoleh }\end{array}$ & 36 & 36 \\
\hline 2 & $\begin{array}{l}\text { Skor yang } \\
\text { diperoleh }\end{array}$ & 27 & 32 \\
\hline 3 & $\begin{array}{l}\text { Prosentase } \\
\text { keterlaksanaan }\end{array}$ & $75 \%$ & $88,89 \%$ \\
\hline
\end{tabular}

Berdasarkan tabel di atas, skor aktivitas guru pada siklus II pertemuan 1 sebesar 27 dengan prosentase sebesar $75 \%$ pada kategori baik, sedangkan pada pertemuan 2 diperoleh skor sebesar 32 dengan prosentase sebesar $88,89 \%$ pada kategori sangat baik. Kegiatan siswa sudah berjalan dengan baik dibanding siklus sebelumnya, tapi terdapat pula kekurangan dalam pelaksanaannya yaitu siswa masih terpengaruh oleh kondisi diluar kelas sehingga menyebabkan suasana kelas menjadi sedikit ribut.

2. Data Pembentukan sikap disiplin siswa

Untuk mengetahui Pembentukan sikap disiplin siswa, dilakukan observasi oleh observer. Dari hasil observasi Pembentukan sikap disiplin siswa diperoleh data sebagai berikut :

Tabel 5

Ringkasan Pembentukan Sikap Disiplin Siswa Siklus II

\begin{tabular}{|l|l|l|l|}
\hline \multirow{2}{*}{ No } & \multicolumn{2}{|c|}{ Idikator } & \multicolumn{2}{c|}{ Siklus II } \\
\cline { 3 - 4 } & $\begin{array}{l}\text { Pertemua } \\
\mathrm{n} \mathrm{1}\end{array}$ & \multicolumn{1}{|c|}{$\begin{array}{c}\text { Pertemuan } \\
2\end{array}$} \\
\hline 1 & $\begin{array}{l}\text { Skor yang harus } \\
\text { diperoleh }\end{array}$ & 20 & 20 \\
\hline 2 & $\begin{array}{l}\text { Skor yang } \\
\text { diperoleh }\end{array}$ & 14 & 18 \\
\hline 3 & Prosentase & $75 \%$ & $90 \%$ \\
\hline 4 & Kategori & Tinggi & $\begin{array}{l}\text { Sangat } \\
\text { Tinggi }\end{array}$ \\
\hline
\end{tabular}

Berdasarkan tabel hasil observasi di atas skor Pembentukan sikap disiplin siswa pada pertemuan II adalah 14 dengan prosentase sebesar $75 \%$ pada kriteria tinggi. Sedangkan pada pertemuan 2 diperoleh skor Pembentukan sikap disiplin siswa 18 dengan prosentase sebesar 90\% pada kriteria sangat tinggi. Berdasarkan hasil observasi Pembentukan sikap disiplin siswa selama proses pembelajaran berlangsung dapat dilihat bahwa kegiatan siswa yang sudah berjalan dengan baik adalah kesiapan dan antusiasme siswa dalam mengikut kegiatan pembelajaran serta interaksi dengan siswa sudah lebih baik dari siklus sebelumnya. Selain itu terdapat pula kekurangan pada pelaksanaan pembelajaran, seperti :

a) Masih ada siswa yang kurang aktif dalam mengerjakan soal latihan yang diberikan.

b) Dari hasil evaluasi, masih banyak siswa yang belum dapat menyelesaikan soal.

\section{Evaluasi}

Data lengkap tentang ketuntasan belajar siswa dapat dilihat pada tabel berikut di bawah ini.

Tabel 6.

Data Prestasi Belajar Siswa Siklus II

\begin{tabular}{|l|l|}
\hline Tes & Siklus II \\
\hline Jumlah Siswa & 31 \\
\hline Nilai Total & 2220 \\
\hline Nilai Rata-rata & 71,61 \\
\hline Siswa Yang Tidak Tuntas & 4 \\
\hline Siswa Yang Tuntas & 27 \\
\hline Nilai Tertingi & 90 \\
\hline Nilai Terendah Ketuntasan & 40 \\
\hline $\begin{array}{l}\text { Persentase } \\
\text { Klasikal }\end{array}$ & $87,10 \%$ \\
\hline Kategori & Tuntas \\
\hline
\end{tabular}

Evaluasi dilakukan pada akhir siklus yaitu pada pertemuan ketiga. Sebelum melakukan evaluasi guru mengingatkan kembali tentang materi yang diajarkan pada pertemuan sebelumnya. Evaluasi ini bertujuan untuk mengetahui apakah siswa sudah benar-benar memahami dengan baik materi yang telah diajarkan. Dari hasil evaluasi diperoleh data tentang prestasi belajar siswa. Data tersebut dianalisis dan diperoleh nilai rata-rata siswa 71,61 dengan nilai tertinggi 90 dan terendah 40 dengan ketuntasan klasikal $87,10 \%$.

Dari tabel 6 tersebut terlihat bahwa presentase ketuntasan belajar siswa sudah memenuhi kriteria yang ditetapkan yakni $\geqslant 85 \%$.

4) Refleksi

Dari hasil observasi dan evaluasi hasil belajar siswa diperoleh bahwa indikator kerja sudah tercapai sudah memenuhi kriteria yang ditetapkan yakni $\geqslant 85 \%$, walaupun masih ada beberapa kekurangan. Misalnya cara mengajukan pertanyaan dan membimbing siswa menyajikan hasil diskusi kelompok. Pada siklus II ini masih ada kelompok yang anggotanya tidak kompak. Walaupun guru sudah berusaha memotivasi mereka, bahwa jika tidak mencoba, maka kita tidak tahu salah benarnya.

\section{Pembahasan}


Penelitian tindakan kelas ini dilaksanakan sebagai upaya untuk mendeskripsikan penerapan metode sosiodrama untuk pembentukan sikap disiplin siswa kelas VII SMP Negeri 21 Mataram. Penelitian ini dilakukan dalam dua siklus yang didasarkan pada cakupan materi pokok bilangan.

Berdasarkan analisis data prestasi belajar siswa pada siklus I diperoleh nilai rata-rata siswa 70,32 dengan nilai tertinggi 80 dan nilai terendah 45, dengan persentase kelas $74,20 \%$, terlihat bahwa persentase ketuntasan belajar siswa pada siklus I belum memenuhi kriteria yang ditetapkan yakni $\geqslant 85 \%$. Hasil evaluasi ini juga menunjukkan bahwa terdapat 8 orang siswa masih belum tuntas belajarnya. Hal ini disebabkan karena terdapat pula kekurangan antara lain: sebagian besar siswa tidak serius pada waktu kerja kelompok sehingga kerjasama antara anggota kelompok kurang optimal, sebagian besar siswa masih takut atau malu untuk bertanya kepada guru, ada siswa yang tidak betah/tidak cocok dengan anggota kelompoknya sehingga kerjasama kelompok kurang optimal, kurang partisipasi siswa dalam menyimpulkan hasil belajar, guru dalam menjelaskan materi dengan suara yang kurang keras sehingga banyak siswa yang bermain-main, guru kurang menekankan kepada siswa supaya saling membantu dalam mengerjakan tugas antara siswa kelompoknya, dan siswa masih terpengaruh oleh kondisi di luar kelas sehingga menyebabkan suasana kelas menjadi sedikit ribut. Kekurangan-kekurangan tersebut menyebabkan rendahnya rata-rata pembentukan sikap disiplin siswa pada siklus I yaitu pertemuan 1 sebesar $35 \%$ menjadi $55 \%$ pada pertemuan 2. Sedangkan kegiatan guru belum dilaksanakan dengan baik yaitu pada siklus I pertemuan 1 dengan persentase sebesar $36,11 \%$ menjadi $58,33 \%$ pada pertemuan 2 .

Pembelajaran siklus II guru melakukan perbaikan terhadap kekurangan-kekurangan yang terdapat pada siklus I, dengan tetap menerapkan metode sosiodrama. Adapun tindakan-tindakan yang dilakukan untuk memperbaiki kekurangan tersebut adalah meminta kepada siswa untuk mengerjakan tugas pada waktu kerja kelompok, meminta kepada siswa agar mencoba mengerjakan soal latihan yang diberikan, bukan hanya menyalin jawaban temannya saja. Hasil analisis observasi Pembentukan sikap disiplin siswa pada siklus II diperoleh bahwa Pembentukan sikap disiplin siswa dikategorikan aktif.

Setelah dilakukan tindakan perbaikan pada siklus II guru memberikan evaluasi untuk mengetahui prestasi belajar siklus II. Pada siklus II diperoleh diperoleh nilai rata-rata siswa 71,61 dengan nilai tertinggi 90 dan terendah 40 dengan ketuntasan klasikal 87,10\%. Hasil yang didapat pada siklus II meningkat jika dibandingkan dengan hasil evaluasi pada siklus I, yaitu dengan nilai rata-rata siswa 70,32 dengan nilai tertinggi 80 dan nilai terendah 45 , dengan persentase kelas $74,20 \%$. Hal ini didukung oleh keaktifan siswa dalam berdiskusi kelompok, walaupun pada kenyataannya masih ada kelompok yang kurang aktif. Siswa sudah aktif dalam mengerjakan soal latihan yang diberikan, dan tidak malu bertanya pada guru atau temanya jika mengalami kesulitan. Walaupun pada dasarnya masih ada siswa yang kurang aktif dalam mengerjakan soal latihan. Hal ini disebabkan pada waktu proses pembelajaran siswa masih terpengaruh oleh kondisi di luar kelas. Sehingga pada waktu penyampaian konsep siswa tidak terlalu memperhatikan gurunya.

Kegiatan pembelajaran guru juga mengalami peningkatan, yaitu pada siklus II pertemuan 1 sebesar 27 dengan prosentase sebesar $75 \%$ pada kategori baik, sedangkan pada pertemuan 2 diperoleh skor sebesar 32 dengan prosentase sebesar $88,89 \%$ pada kategori sangat baik. Sedangkan pembentukan sikap disiplin siswa juga mengalami peningkatan yaitu pada pertemuan 1 adalah 14 dengan prosentase sebesar $75 \%$ pada kriteria tinggi. Sedangkan pada pertemuan 2 diperoleh skor Pembentukan sikap disiplin siswa 18 dengan prosentase sebesar 90\% pada kriteria sangat tinggi.

Secara keseluruhan hasil dari penelitian ini menunjukkan bahwa penerapan metode sosiodrama dapat meningkatkan pembentukan sikap disiplin dan hasil belajar PPKn siswa kelas VII pada materi pokok bilangan di SMP Negeri 21 Mataram. Hal ini disebabkan karena dalam penerapan metode sosiodrama, siswa sendiri belajar melalui partisipasi secara aktif untuk menemukan suatu konsep atau prinsip, dari pengalaman yang mereka miliki serta siswa dapat belajar dalam kelompok-kelompok kecil yang memiliki kemampuan yang berbeda-beda. Hal ini juga didukung oleh hasil penelitian bahwa metode sosiodrama digunakan, karena akan mengasah kemapuan siswa dalam memecahkan masalah, mengeksperisikan sesuatu secara efektif serta menekankan siswa pada makna ide-ide yang dapat diperkuat melalui aktifitas yang kreatif dengan cara melihat sesuatu yang lebih luas[14]. Senada dengan pendapat lainnya metode sosiodrama merupakan suatu bentuk pembelajaran yang bertujuan mengefektifkan partisipasa siswa dalam pembelajaran serta mengurangi adanya dominasi partisipasi oleh satu atau beberapa orang saja dalam diskusi[15]. Sehingga terjadi hubungan guru dan siswa serta siswa dan siswa yang baik dan suasana belajar yang menyenangkan dengan demikian siswa akan lebih giat dan serius sehingga dapat meningkatkan pembentukan sikap disiplin dan hasil belajar PPKn siswa di SMP Negeri 21 Mataram terlihat dari hasil ketuntasan klasikal 87,10\%.

Hal ini didukung dari hasil wawancara peneliti terhadap beberapa siswa di SMP Negeri 21 Mataram, bahwa setelah proses penerapan metode sosiodrama siswa mengemukakan bahwa penerapan metode sosiodrama dapat meningkatkan minat belajar siswa dapat dilihat dari kebiasaan siswa yang selalu aktif dalam belajar. Meningkatkan motivasi belajar siswa terutama dalam mengerjakan soal latihan, menjadikan siswa serius dalam belajar. Hal ini terbukti dari tidak adanya siswa yang keluar masuk pada saat proses belajar mengajar, menjadikan sebagian besar siswa serius pada waktu kerja kelompok sehingga kerjasama antara anggota kelompok sudah optimal, menjadikan sebagian besar siswa tidak takut atau malu untuk bertanya kepada guru, menguasai materi dengan baik dan siswa menjadi lebih aktif dalam belajar, melatih daya ingat siswa tentang suatu konsep/informasi, melatih daya pikir kritis siswa terhadap suatu masalah dan memberikan pengalaman belajar kepada siswa, karena siswa banyak berperan aktif dalam pembelajaran sehingga pembelajaran menjadi bermakna.

Hal ini dapat dilihat dari hasil analisis dan pembahasan diperoleh keterlaksanaan pembelajaran mengalami peningkatan dari siklus I pertemuan 1 dengan persentase sebesar $36,11 \%$ menjadi $58,33 \%$ pada 
pertemuan 2 sedangkan pada siklus II pertemuan 1 dengan persentase sebesar 58,33\% menjadi $88,89 \%$ pada pertemuan 2. Sedangkan pembentukan sikap disiplin mengalami peningkatan dari siklus II pertemuan 1 dengan persentase sebesar 35\% menjadi 55\% pada pertemuan 2 sedangkan pada siklus II pertemuan 1 dengan persentase sebesar $75 \%$ menjadi $90 \%$ pada pertemuan 2. Terlihat juga dari ketuntasan klasikal pada siklus I yaitu $74,20 \%$ mengalami peningkatan pada siklus II sebesar $87,10 \%$.

\section{SIMPULAN DAN SARAN}

Berdasarkan hasil penelitian disimpulkan bahwa penerapan metode sosiodrama dapat meningkatkan pembentukan sikap disiplin dan hasil belajar siswa siswa kelas VII SMP Negeri 21 Mataram. Hal Ini dikarenakan adanya peningkatan pembentukan sikap disiplin dan hasil belajar, serta kegiatan mengajar yang dilakukan oleh guru, karena penerapan metode sosiodrama memiliki kelebihan dapat memberikan kesempatan kepada para siswa untuk lebih aktif dalam proses belajar mengajar dan dapat memberikan kesempatan pada para siswa untuk mengasah keterampilan berdiskusi.

Dengan demikian hasil penelitian menyarankan pada guru dapat mencoba metoda yang lebih bersifat inovatif dan tidak terikat pada cara lama dan diperlukannya pembinaan daya berkarya terutama menulis dengan menggunakan metode sosiodrama dan lebih untuk memberdayakan proses pembelajaran agar lebih bermakna dan bermutu.

\section{UCAPAN TERIMA KASIH}

Penulis mengucapkan terima kasih kepada editor yang senantiasa memberikan saran dan masukan kepada penulis sehingga artikel ilimiah ini selesai dengan baik.

\section{DAFTAR RUJUKAN}

[1] C. N. Aulina, "Penanaman disiplin pada anak usia dini," Pedagog. J. Pendidik., vol. 2, no. 1, pp. 36-49, 2013.

[2] T. Lickona, "Pendidikan Karakter: Panduan Lengkap Mendidik Peserta Didik Menjadi Pintar dan Baik," Bandung Nusa Media, diterjemahkan oleh S. Lita Irfan M. Zakkie, 2013.

[3] E. Mulyasa, "Manajemen dan kepemimpinan kepala sekolah," Jakarta Bumi Aksara, 2012.

[4] A. Suharyanto, "Peranan Pendidikan Kewarganegaraan Dalam Membina Sikap Toleransi Antar Siswa," JPPUMA J. Ilmu Pemerintah. dan Sos. Polit. Univ. Medan Area, vol. 1, no. 2, p. 12, 2017.

[5] S. Dharma and R. Siregar, "Internalisasi Karakter melalui Model Project Citizen pada Pembelajaran Pendidikan Pancasila dan Kewarganegaraan," JUPIIS J. Pendidik. Ilmu-ilmu Sos., vol. 6, no. 2, pp. 132-137, 2015.

[6] L. N. Ahyani and D. R. Dhania, "Metode sosiodrama dalam meningkatkan kecerdasan moral anak," J. Sos. dan Budaya, vol. 4, no. 2, 2011.

[7] K. A. Purnami, N. N. Garminah, M. Hum, and I. K. Sudarma, "Pengaruh Metode Sosiodrama Berbantuan Cerita Rakyat Terhadap Keterampilan Berbicara Siswa Kelas V," Mimb. PGSD Undiksha, vol. 2, no. 1, 2014.

[8] A. Suharsimi, "Prosedur penelitian suatu pendekatan praktik,” Jakarta: Rineka Cipta, 2006.
[9] M. N. Purwanto, Prinsip-prinsip dan teknik evaluasi pengajaran. Remaja Rosdakarya, 2000.

[10] Y. Riyanto, "Metodologi Penelitian Kualitatif dan Kuantitatif." Surabaya: Unesa University Press, 2007.

[11] Sugiyono, Metode Penelitian Kuantitatif, Kualitatif, dan R\&D. 2013.

[12] R. B. Mardalis, "Analisis pengaruh kualitas pelayanan terhadap kepuasan penumpang jasa transportasi KA Sancaka jurusan Yogyakarta-Surabaya di stasiun Solo Balapan," Puslinet\&UPT, Perpust. Pus., 2004.

[13] A. Sugiyono, "Pengantar Statistik Pendidikan," Jakarta Graf. Persada, 2004.

[14] D. G. B. Erawan, "Penggunaan metode sosiodrama untuk meningkatkan kemampuan berwawancara dengan berbagai kalangan pada siswa kelas VIII SMP Mutiara Singaraja," J. Santiaji Pendidik., vol. 4, no. 1, 2014.

[15] B. Slameto, "Faktor-faktor yang mempengaruhi," Jakarta: Rineka Cipta, 2010. 